\title{
Plastic Deformation Properties of Magnesium Alloy AZ61
}

Ivana Hlaváčová, Peter Palček, Mária Chalupová, Zuzana Dresslerová

Department of Materials Engineering, Faculty of Mechanical Engineering, University of Žilina Univerzitná 8215/1, 010 26, Žilina, Slovak Republic. ivana.hlavacova@ fstroj.uniza.sk

The main object of this research was the influence of plastic deformation on magnesium alloy AZ61 with 0.5 wt. \% of Ca. Tested specimens were loaded by three - point bending test and by pressure deformation. Hardeing and softening were measured also. Specimens were studied in two structural states: as - cast state and in state after heat treatment. During three - point bending test specimens were plastically deformed by dislocation slip and twinning. The compression loading of experimental specimens after heat treatment led to slip and twinning plastic deformation. Cracks were created in the surrounding area of the indentation and there was also cracking of intermetallic phases present in the microstructure. Changes in the intensity and distribution of plastic deformation were caused by deformation strengthening and shifting of grain boundaries. Grain reorientation and strengthening of neighbouring grains occurred during the growth of plastic deformation and the hardness was increased. After reaching annealing temperature of $300{ }^{\circ} \mathrm{C}$, decrease of the material hardness was observed.

Keywords: magnesium alloy, plastic deformation, twinning, softening, hardening

\section{Acknowledgment}

The research was supported partially by SK VEGA grant No. 1/0797/12 and EÚ - ITMS: 26110230004. Authors gratefully acknowledge this support.
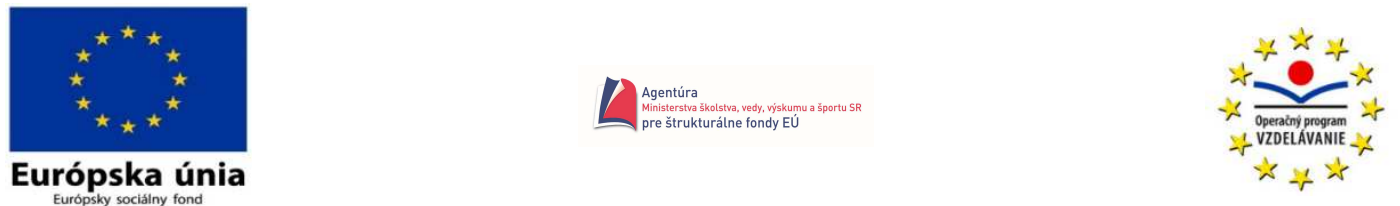

"Modern education for knowledge society / Project is supporting by financial source of European Union"

Project: Systematization of the Advanced Technologies and Knowledge transfer between industry and universities - ITMS: 26110230004

\section{References}

[1] ZHU, R., WU, Y. J., et al.: Cyclic Softening of Ultrafine - grained AZ31 Magnesium Alloy Processed by Equal - channel Angular Pressing. In Materials Letters. 2011. Volume 65, Issues 23 - 24, p. 3593 - 3596.

[2] TILlOVÁ, E., CHALUPOVÁ, M., et al.: Quality Control of Microstructure in Recycled Al - Si Cast Alloys. In Manufacturing Technology. 2011. Volume 11, No. 11, p. 70 - 76. ISBN 987 - 80 - 7414-415- 8

[3] MORDIKE, B.L., EBERT, T.: Magnesium Properties- applications - potential. In Materials Science and Engineering A. 2001. Volume 302, Issue 1, p. $37-45$.

[4] BARNETT, M. R.: Twinning and the Ductility of Magnesium Alloys Part I: “Tension" Twins. In Materials Science \& Engineering. 2007. Volume 464, Issues 1 - 2, p. 1 - 7.

[5] BARNETT, M. R.: Twinning and the Ductility of Magnesium Alloys Part II: "Contraction" Twins. In Materials Science \& Engineering. 2007. Volume 464, Issues 1 - 2, p. 8 - 16.

[6] YOO, M. H.: Slip, Twinning, and Fracture in Hexagonal Close - packed Metals. In Metallurgical Transactions A. 1981. Volume 12, Issue 3, p. $409-418$.

[7] SHAMSI, M., SANJARI, M. et al.: Study of Fractional Softening of AZ31 Magnesium Alloy under Multistage Hot Deformation. In Materials Science and Technology. 2009. Volume 25, No. 8, p. 1039 - 1045.

[8] LICHÝ, P., BEŇO, J., CAGALA, M.: Inoculant Addition Effect on Thermomechanical and Thermophysical Properties of Mg-Sr Magnesium Alloy. In Manufacturing Technology. 2013. Volume 13, No. 1, p. 64 - 67. ISSN $1213-2489$

[9] JIANG, L., JONAS, J . J. et al.: Twinning and Texture Development in Two Mg Alloys Subjected to Loading Along Three Different Strain Paths. In Acta Materialia. 2007. Volume 55, Issue 11, p. 3899 - 3910.

[10] LOU, C., ZHANG, X., et al.: Characteristics of Twin Lamellar Structure in Magnesium Alloy during Room 
Temperature Dynamic Plastic Deformation. In Journal of Materials Science \& Technology. 2013.

[11] JOHNSON, W., WALTON, A.C.: An Experimental Investigation of the Energy Dissipation of a Number of Car Bumpers under Quasi-static Lateral Loads. In International Journal of Impact Engineering. 1983. Volume 1, Issue 3, p. $301-308$.

[12] PALČEK, P., HLAVÁČOVÁ, I., CHALUPOVÁ, M. Influence of AZ61 Structure on the Plastic Deformation Around a Crack. In DAS. 2012. ISBN 978-86-7083-762-1, p. $134-135$.

[13] PALČEK, P., HLAVÁČOVÁ, I., CHALUPOVÁ, M.: The Study of Plastic Deformation in the Crack Surrouding in AZ61 Alloy. In FME Transactions. 2013. Volume 41, No. 2, p. 103 - 108 ISSN $1451-2092$

[14] KOIKE, J. 2005. Enhanced Deformation Mechanisms by Anisotropic Plasticity in Polycrystalline Mg Alloys at Room Temperature. In Physical Metallurgy and Materials Science. Japan. 2005. Volume 36, Issue 7, p. 1689 1696.

[15] GEHRMANN, R., FROMMERT, M. M, GOTTSTEIN, G. 2005. Texture Effects on Plastic Deformation of Magnesium. In Materials Science and Engineering A. Germany. 2005. Volume 395, Issue 1- 2, p. 338 - 349.

[16] AFRIN, N., CHEN, D.L., CAO, X., JAHAZI, M. 2007. Strain Hardening Behavior of a Friction Stir Welded Magnesium Alloy. In Scripta Materialia. Canada. 2007. Volume 57, Issue 11, p. 1004 - 1007. 